\title{
AKIBAT HUKUM PEMBATALAN PENDAFTARAN MEREK TERHADAP HAK PENERIMA LISENSI MEREK MENURUT UU NO. 15 TAHUN 2001
}

\author{
Agus Mardianto \\ Fakultas Hukum Universitas J enderal Soedirman Purwokerto J awa Tengah \\ E-mail: agusmardianto39@yahoo.co.id
}

\begin{abstract}
Trade globalization has made trade mark becomes very important, especially in relation to a fair business competition. A trade mark is a sign that functions as a distinguished from those of others, quality guarantee and source of origin. Owner of a trade mark registered reserves exclusive right to use that trade mark for a period of time or may grant permission to other parties to use the trade mark. Permission to other parties should be given through a letter of agreement for permission to use (not transfer of ownership) that trade mark for a certain period of time, and this is accordingly called licence. Registration of a trade mark in the general list of trade mark can be cancelled upon request with an argument that the trade mark has a basic similarity with a previously registered trade mark, or the registration was made for cruel intention. This paper discusses licence and cancellation of a trademark, as well as the consequences of trade mark cancellation for the licensee. Cancellation of a trade mark registration results in termination of a trade mark license agreement, but the licensee may reserve his right until the completion of agreement period.
\end{abstract}

Key words : exclusive right, license agreement, licensee.

\begin{abstract}
Abstrak
Globalisasi perdagangan telah membuat merek dagang menjadi sangat penting. Sebuah merek dagang adalah tanda yang berfungsi sebagai dibedakan dari orang lain, jaminan kualitas dan sumber asal. Pemilik merek dagang terdaftar memiliki hak eksklusif untuk menggunakan merek dagang dalam jangka waktu tertentu atau memberikan izin kepada pihak lain untuk menggunakannya. Izin kepada pihak lain atau lisensi, harus diberikan melalui surat persetujuan untuk izin untuk menggunakan (tidak mengalihkan kepemilikan) untuk jangka waktu tertentu. Pendaftaran merek dagang dalam daftar umum merek dagang dapat dibatalkan atas permintaan dengan argumen bahwa merek dagang memiliki kesamaan dasar dengan merek dagang terdaftar sebelumnya, atau pendaftaran itu dibuat untuk maksud kejam. Pembatalan hasil pendaftaran merek dagang penghentian perjanjian lisensi merek dagang, namun penerima Lisensi dapat berhak sampai selesainya masa perjanjian.
\end{abstract}

Kata kunci : hak eksklusif, perjanjian lisensi, pemegang lisensi.

\section{Pendahuluan}

Pengaruh globalisasi di segala bidang kehidupan masyarakat, baik di bidang sosial, ekonomi, maupun budaya semakin mendorong laju perkembangan perekonomian masyarakat. Di samping itu, dengan semakin meningkatnya Perkembangan teknologi informasi dan sarana transportasi telah menjadikan kegiatan di sektor perdagangan barang maupun jasa meningkat secara pesat. Kecenderungan meningkatnya arus perdagangan barang dan jasa tersebut akan terus berlangsung sejalan dengan partumbuhan ekonomi nasional yang semakin baik.
Beberapa negara semakin mengandalkan kegiatan ekonomi dan perdagangannya pada produk-produk yang dihasilkan atas dasar kemampuan intelektual manusia.

Mengingat kenyataan tersebut, merek sebagai salah satu karya intelektual manusia yang akrab hubungannya dengan kegiatan ekonomi dan perdagangan memegang peranan yang sangat penting. Sejak industrialisasi berkembang, merek menjadi faktor kunci dunia perdagangan. Dalam era perdagangan global, peranan merek menjadi penting terutama untuk men- 
jaga persaingan bisnis yang sehat. ${ }^{1}$ Merek adalah tanda yang berupa gambar, nama, kata, huruf-huruf, angka-angka, susunan warna, atau kombinasi dari unsur-unsur tersebut yang memiliki daya pembeda dan digunakan dalam kegiatan perdagangan barang atau jasa. ${ }^{2}$ Dalam perkembangan lebih lanjut, beberapa negara maju telah memasukan tanda-tanda tiga dimensi (three-dimensional signs) seperti bentuk sebuah produk (shapes of products) atau kemasan (packaging) sebagai merek. $^{3}$ Menurut Singapore Treaty on the Law of the Trade Mark 2006 merek dapat berupa warna saja, gambar tiga dimensi atau merek dalam bentuk hologram, dan Motion Mark. ${ }^{4}$

Tidak semua tanda dapat didaftar sebagai merek. Hanya tanda-tanda yang memenuhi syarat yang dapat didaftar sebagai merek, seperti mempunyai daya pembeda; tanda tersebut tidak bertentangan dengan peraturan perundang-undangan yang berlaku, moralitas agama, kesusilaan, atau ketertiban umum; bukan tanda bersifat umum dan tidak menjadi milik umum; atau bukan merupakan keterangan atau berkaitan dengan barang atau jasa yang dimohonkan pendaftarannya; tanda tersebut juga tidak

1 Setiap persaingan yang bertentangan dengan praktek yang jujur dalam industri dan bisnis dianggap sebagai persaingan curang. Tindakan-tindakan yang dianggap sebagai persaingan curang menurut Konvensi Paris 1883 adalah semua tindakan yang menimbulkan kebingungan dengan berbagai cara apapun yang terkait dengan pendirian, barang-barang atau kegiatan industri atau bisnis dari competitor. Valerie Selvie, "Perlindungan Hukum Merek Terkenal Tidak Terdaftar di Indonesia", J urnal Gloria J uris, Vol. 6, No. 2, Mei - Agustus 2006, hlm. 157

2 Lihat dan bandingkan dengan Gloria Gita Putri Ginting, "Perlindungan Hukum Dalam Bidang Merek", Jurnal Suloh, Vol. III No. 1 April 2005, hlm. 26.

3 Tomi Suryo Utomo, 2010. Hak Kekayaan Intelektual (HKI) di Era Global (Sebuah Kajian Kontemporer), Yogyakarta: Graha IImu, hlm. 209. Bandingkan dengan Valerie Selvie yang menulis: a trade mark is a sign used to distinguished good or service dealt with or provided by other. Sign includes 'any letter, word, name, signature, numeral, device, brand, healing, label, ticket, aspect of packaging, shape, colour, sound or scent' or any combination of these. Valerie Selvie, "Domain Name and Mark Issues on The Internet: The Perspective of Australian Law", J urnal Gloria Juris, Vol. 5, Nomor 3, SeptemberDesember 2005, hlm. 224.

4 Ditandatangani 28 Mei 2006, diberlakukan sejak 16 Maret 2009. Kehadiran Singapore Treaty merupakan perkembangan baru dalam bidang hukum merek, karena telah menambah luasnya cakupan merek. Syafrinaldi, "Urgensi dan Permasalahan Harmonisasi Undang-Undang Merek Terhadap Protokol Madrid", J urnal Hukum Bisnis, Vol. 28 No. 2 Tahun 2009, hlm. 8-9 mempunyai persamaan dengan merek lain yang terdaftar terlebih dahulu.

Fungsi merek ${ }^{5}$ adalah sebagai tanda pengenal untuk membedakan produk perusahaan yang satu dengan produk perusahaan yang lain (product identity), sarana promosi dagang (means of trade promotion), jaminan atas mutu barang atau jasa (quality guarantee), dan penunjukan asal barang atau jasa yang dihasilkan (source of origin).

Pasal 3 Undang-Undang Nomor 15 Tahun 2001 tentang Merek (selanjutnya disingkat UU Merek) menyebutkan bahwa Hak Merek adalah hak eksklusif yang diberikan oleh negara kepada pemilik merek yang terdaftar dalam Daftar Umum Merek untuk jangka waktu tertentu dengan menggunakan sendiri merek tersebut atau memberikan izin kepada pihak lain untuk menggunakannya.

Hak Merek diberikan oleh Negara karena Hak Merek tidak lahir secara otomatis seperti halnya Hak Cipta. Hak Merek lahir karena pendaftaran. ${ }^{6}$ Perlindungan hukum merek hanya akan berlangsung apabila hal tersebut dimintakan pendaftaran. Pendaftaran adalah mutlak untuk terjadinya hak merek, tanpa pendaftaran tidak ada hak merek, juga tidak ada perlindungan. ${ }^{7}$ Pemilik merek terdaftar dapat menggunakan sendiri mereknya untuk jangka waktu 10 tahun dan jangka waktu perlindungan tersebut dapat diperpanjang kembali. Pemilik merek terdaftar dapat melakukan pengalihan hak atas mereknya dengan cara pewa-

\footnotetext{
5 Abdulkadir Muhammad, 2001, Kajian Hukum Ekonomi Hak Kekayaan Intelektual, Citra Aditya: Bandung, hlm. 120-121

6 Hak merek timbul berdasarkan pendaftaran yang dilandasi itikad baik. Permohonan pendaftaran merek harus memenuhi persyaratan materil sebagaimana diatur daIam Pasal 4 - Pasal 6 UU Merek dan persyaratan formil (persyaratan administrasi) sebagaimana diatur dalam Pasal 7 dan Pasal 8 UU Merek. H.R. Tonny Suryadi Wij aya, Perlindungan Merek di Indonesia Menurut Undang-Undang Nomor 15 Tahun 2001 Tentang Merek, Perspektif Hukum, Volume 7 Nomor 1, Mei 2007, hlm. 58,; Noegroho Amin stiarto, Hak Atas Kekayaan Intelektual dan Hak Kekayaan Intelektual Tradisional Dalam Konteks Otonomi Daerah, J urnal Mimbar Hukum Edisi Tahun 2000, hlm 68.

7 Pendaftaran Hak atas merek yang sifatnya wajib tersebut merupakan suatu konsekuensi sistem konstitutif yang dianut oleh Undang-undang Nomor 15 Tahun 2001 yang mengatur tentang merek. Agung Sujatmiko, Prinsip Hukum Kontrak Dalam Lisensi Merek, J urnal Mimbar Hukum, Volume 20, nomor 2, J uni 2008, hlm. 251.
} 
risan, wasiat, hibah, perjanjian, atau sebab-sebab lain yang di-benarkan oleh peraturan perundang-undangan.

Selain dapat menggunakan sendiri mereknya atau mengalihkan hak mereknya, Pemilik merek terdaftar dapat memberikan izin kepada pihak lain untuk menggunakan hak mereknya. Pemberian izin inilah yang disebut lisensi. Bentuk lisensi adalah perjanjian antara pemilik merek (pemberi lisensi) dengan pihak yang akan menggunakan hak merek (penerima lisensi). Jadi lisensi merek bukan peralihan hak merek tetapi hanya pemberian izin untuk memanfaat secara ekonomis hak atas merek.

Perjanjian lisensi merek merupakan salah satu sarana untuk melindungi suatu merek dari tindakan pelanggaran dan kejahatan merek yang berupa pemakaian merek tanpa izin dan pemalsuan merek (infringement). Perjanjian lisensi merek tidak hanya memberi manfaat bagi pemilik merek selaku pemberi lisensi (Iicensor), melainkan juga penerima lisensi (Iicensee). Bagi pemilik merek, dengan adanya perjanjian lisensi, mereknya akan semakin dikenal oleh konsumen dan dilindungi oleh hukum. Sedangkan bagi penerima lisensi, dapat meng-gunakan merek orang lain secara aman dan legal. Penggunaan Merek terdaftar di Indonesia oleh penerima Lisensi dianggap sama dengan penggunaan Merek tersebut di Indonesia oleh pemilik Merek.

Terhadap merek yang sudah terdaftar daIam Daftar Umum Merek, masih dapat di-intakan pembatalan pendaftaran merek. Gugatan pembatalan pendaftaran merek dapat diajukan oleh pihak yang berkepentingan berdasarkan alasan sebagaimana dimaksud dalam Pasal 4, Pasal 5, atau Pasal 6 UU Merek. ${ }^{8}$ Pembatalan pendaftaran merek dilakukan dengan mencoret merek yang bersangkutan dari Daftar umum Merek. Pembatalan dan pencoretan pendaftar-

\footnotetext{
8 Sebagai contoh adalah kasus gugatan pembatalan pendaftaran merek yang dilakukan oleh ADIDAS AG J erman terhadap Kim Sung Soo warganegara Korea, karena merek "Adidia" milik tergugat mempunyai persamaan pada pokoknya dengan merek terkenal "Adidas" milik Penggugat. Selengkapnya lihat perkara Nomor: 13/ MEREK/ 2010/ PN. Niaga.J KT. PST.
}

an merek mengakibatkan berakhirnya perlindungan hukum merek yang bersangkutan.

Pembatalan pendaftaran ${ }^{9}$ merek mempunyai dampak langsung terhadap perjanjian lisensi merek yang dibuat oleh pemilik merek (yang dibatalkan) dengan penerima lisensi, karena pembatalan pendaftaran merek akan mengakibatkan berakhirnya perjanjian lisensi merek. Dengan berakhirnya perjanjian lisensi tentu berakibat terhadap kepentingan penerima lisensi merek, terutama yang berkaitan dengan hak penerima lisensi merek.

Berdasarkan hal tersebut penulis tertarik untuk mengkaji mengenai bagaimana akibat hukum pembatalan pendaftaran merek terhadap hak penerima lisensi merek menurut UU Merek. Tulisan ini akan membahas tentang lisensi merek, pembatalan pendaftaran merek dan akibat pembatalan pendaftaran merek terhadap hak penerima lisensi merek.

\section{Pembahasan \\ Lisensi Merek}

Pengertian Lisensi menurut Pasal 1 angka 13 UU Merek adalah izin yang diberikan oleh pemilik merek terdaftar kepada pihak lain meIalui suatu perjanjian berdasarkan pada pemberian hak (bukan Pengalihahan hak) untuk menggunakan merek tersebut, baik untuk seluruh atau sebagian jenis barang dan/atau jasa yang didaftarkan dalam jangka waktu dan syarat tertentu. ${ }^{10}$

\footnotetext{
9 Kasus persengketaan perjanjian lisensi yang berlanj ut ke sengketa pembatalan merek adalah kasus minuman "cap kaki tiga". Wen Ken Drug Co, Pte Ltd selaku produsen cap kaki tiga melayangkan gugatan pembatalan merek dengan lukisan Badak milik Tjioe Budi Yuwono, salah satu pemegang saham PT Sinde Budi Sentosa. Gugatan dilayangkan lantaran merek milik Tjioe Budi mirip dengan merek Cap Kaki Tiga dengan lukisan Badak milik Wen Ken Drug. Selengkapnya lihat perkara Nomor: 29/ Merek/ 2010/ PN. NIAGA.J KT. PST.

${ }^{10}$ Konsep dasar pemberian Hak Kekayaan Intelektual (HKI) karena pemilik hak sudah berkorban dan mencurahkan tenaga, pikiran, waktu dan biaya untuk menghasilkan suatu karya, maka pemilik hak dapat menggunakan haknya sebagai aset atau mengalihkannya pada pihak lain secara social (hibah, wasiat) atau komersial (perjanjian lisensi atau perjanjian penyerahan, dan perjanjian lain), dan memberi perlindungan hukum dari pemekaian hak oleh pihak lain tanpa izin. Venantia Hadiarianti, "Konsep Dasar Pemberian Hak dan perlindungan Hukum Hak kekayaan Intelektual", J urnal Gloria J uris, Vol. 8, No. 2, Mei-Agustus 2008, hlm. 1.
} 
Menurut Black's Law Dicionary lisensi (license) adalah A personal privilege to do some particular act or series of acts on land without possessing any estate or interest therein, and is ordinarily revocable at the will of licensor and is not assignable. The permission by competent authority to do an act which without such permission would be illegal, a trespass, a tort or otherwise would not be allowed. ${ }^{11}$ Secara harfiah lisensi mengandung arti sebagai suatu ijin (hak atau wewenang) yang diberikan oleh pihak yang berwenang atau pihak yang berhak kepada pihak lain untuk melakukan suatu perbuatan atau berbagai macam perbuatan hukum atas sebidang tanah yang bukan miliknya. Perbuatan-perbuatan hukum tersebut apabila dilakukan tanpa ij in dari sipemilik hak merupakan suatu perbuatan yang tidak sah (illegal), perbuatan yang salah atau pelanggaran (trespass), perbuatan yang menimbulkan kerugian (tort) atau perbuatan-perbuatan lain yang termasuk dalam kategori perbuatan yang tidak diperbolehkan (not be allowed).

Gunawan Widjaya memberikan pengertian lisensi sebagai suatu bentuk hak untuk melakukan satu atau serangkaian tindakan atau perbuatan, yang diberikan oleh mereka yang berwenang dalam bentuk izin. Tanpa adanya izin tersebut, tindakan atau perbuatan ter-sebut merupakan tindakan yang terlarang, yang tidak sah, yang merupakan perbuatan melawan hukum. ${ }^{12}$

Berdasarkan pengertian di atas, dapat disimpulkan bahwa lisensi adalah suatu bentuk perjanjian atau kesepakatan (agreement) antara dua pihak. Pihak yang satu (pemberi lisensi / licensor) memperbolehkan pihak yang lain yaitu penerima lisensi (licensee) untuk melakukan suatu jenis perbuatan hukum tertentu, misal-

\footnotetext{
${ }^{11}$ Gunawan Suryomurcito (Ketua Tim), 2006. Laporan Akhir Tentang Kompilasi Bidang Hukum Perjanjian Lisensi, Jakarta: BPHN Departemen Hukum dan Hak Asasi Manusia, hlm. 11.

12 Agung Sujatmiko, "Aspek Yuridis Lisensi Merek dan Persaingan Usaha", Jurnal Hukum Pro J ustitia, UNPAR Bandung, Vol. 26 No.2, April 2008, hlm. 96. Lihat dan bandingkan dengan pengertian lisensi dalam Syafrinaldi, "Hak Milik Intelektual dan Lisensi Sebagai sarana Alih Teknologi", J urnal IImu Hukum, Unis Riau, Vol. 1 No. 1 April 2009, hlm. 17
}

nya menggunakan nama dagang (merek) pemberi lisensi.

Banyak pertimbangan yang dipakai untuk pembuatan perjanjian lisensi seperti: ${ }^{13}$ (a) Lisensi menambah sumber daya pengusaha pemberi lisensi secara tidak langsung; (b) Lisensi memungkinkan perluasan wilayah usaha secara tidak terbatas; (c) Lisensi memperluas pasar dari produk hingga dapat menjangkau pasar yang semula berada diluar pangsa pasar pemberi lisensi; (d) Lisensi mempercepat proses pengembangan usaha bagi industri padat modal; (e) Melalui lisensi, penyebaran produk menjadi lebih mudah dan terfokus pada pasar; (f) Melalui lisensi sesungguhnya pemberi lisensi dapat mengurangi tingkat kompetisi hingga pada suatu batas tertentu; (g) Melalui lisensi, pihak pemberi lisensi maupun penerima lisensi dapat melakukan trade off (atau barter) teknologi; (h) Lisensi memberi keuntungan dalam bentuk nama besar dan goodwill dari pemberi lisensi; (i) Pemberian lisensi memungkinkan pemberi lisensi untuk sampai pada batas tertentu melakukan kontrol atas pengelolaan kegiatan usaha yang dilisensikan.

Pasal 43 ayat (1) UU Merek menyebutkan bahwa pemilik merek terdaftar berhak memberikan lisensi kepada pihak lain dengan perjanjian bahwa penerima lisensi akan menggunakan merek tersebut untuk sebagian atau seluruh jenis barang atau jasa. Menurut ketentuan tesebut, lahirnya hubungan hukum para pihak dalam pemberian lisensi harus dituangkan dalam perjanjian. Perjanjian tersebut tunduk sepenuhnya pada hukum perjanjian yang terdapat dalam Kitab Undangundang Hukum Perdata (KUH Perdata).

Prinsip-prinsip hukum kontrak dalam hukum perdata dapat dipergunakan dalam pembuatan dan pelaksanaan perjanjian lisensi, sebagai dasar yang harus dipatuhi oleh para pihak agar perjanjian lisensi yang dibuat tidak merugikan salah satu pihak dan dapat di-laksanakan secara adil. Prinsip-prinsip hukum kontrak tersebut adalah sebagai berikut. ${ }^{14}$ Pertama

\footnotetext{
${ }^{13}$ Lebih jelasnya lihat Agung Suj atmiko, ibid., hlm. 97-98.

${ }^{14}$ Lihat Agung Sujatmiko, "Prinsip Hukum Kontrak ...", op.cit., hlm. 258-263
} 
adalah prinsip kebebasan berkontrak. Perjanjian lisensi merek dibuat berdasarkan kebebasan berkontrak (freedom of contract). ${ }^{15}$ Kebebasan berkontrak diterapkan dalam perjanjian lisensi merek, dimana para pihak diberi kebebasan untuk merumuskan isi perjanjian lisensi sesuai kehendak masing-masing, misalnya yang menyangkut besar royalty, waktu pembayaran royalty, penyelesaian sengketa dan berakhirnya perjanjian lisensi. Kedua, adalah prinsip kesepakatan, prinsip ini mendasarkan pada ketentuan Pasal 1320 KUH Perdata yang mengatur syaratsyarat sahnya perjanjian, yang menghendaki adanya: (a) Kesepakatan dari para pihak, (b) Kecakapan untuk membuat perjajian, (c) Suatu hal tertentu, (c) Suatu sebab yang halal. Ketiga, adalah prinsip Pacta sunt Servanda. Dalam perjanjian lisensi merek para pihak dituntut dengan itikad baik untuk melaksanakan isi perjanjian dengan baik dan bertanggung jawab. Jika salah satu pihak tidak melaksanakannya, maka pihak lain dapat meminta pertanggungjawaban di depan hukum. Keempat, adalah prinsip kesederajatan. Para pihak dalam perjanjian lisensi (pemberi lisensi dan penerima lisensi) mempunyai kedudukan yang sederajat (sama), sehingga salah satu pihak tidak berkedudukan lebih tinggi dari yang lain. Kelima, adalah Prinsip Profit of Contract. Prinsip ini menekankan para pihak harus mendapat manfaat ekonomis (keuntungan) dari perjanjian lisensi yang dibuat. Pemberi lisensi memperoleh pembayaran royalty dari penerima lisensi, sedangkan penerima lisensi dapat menggunakan merek yang

\footnotetext{
${ }^{15}$ Kebebasan tersebut bukanlah dalam pengertian "sebebas-bebasnya" karena haruslah tetap dilaksanakan pada koridor hukum, kesusilaan dan ketertiban umum yang berlaku. Kontrak yang bertentangan dengan hal tersebut akan mengakibatkan kontrak tersebut menjadi batal demi hokum. Ricardo Simanjuntak, "Asas-Asas Utama Hukum Kontrak Dalam Kontrak Dagang Internasional: sebuah Tinjauan Hukum", J urnal Hukum Bisnis, Vol. 27, No. 4 Tahun 2008, hlm. 14. Menurut A. Bustamin, walaupun secara umum kepada para pihak diberikan kebebasan untuk mengadakan kontrak dan perjanjiannya dianggap lahir sejak terjadinya kesepakatan menyangkut objek atau hal pokok yang merupakan unsur esensial dalam suatu perjanjian, namun masih ada hal-hal pokok yang perlu diperhatikan oleh pihak-pihak yang mengadakan kontrak yaitu syarat sahnya perjanjian. A. Bustamin, "Kebebasan Berkontrak Hubungannya Dengan Perjanjian Baku", J urnal Aktualita, Vol. I, No. 2 Agustus - November 2005, hlm. 65.
}

telah dikenal baik oleh kunsumen, sehingga mudah dipasarkan. Keenam, adalah prinsip itikad baik, prinsip itikad baik telah menjadi salah satu persyaratan dalam pembuatan perjanjian lisensi merek. Para pihak harus menjunjung tinggi prinsip tersebut, agar perjanjian lisensi dapat berjalan dengan baik dan tidak bermasalah di kemudian hari. ${ }^{16}$

Hubungan hukum yang timbul karena perjanjian lisensi demikian penting, maka sebaiknya perjanjian ini dibuat dalam bentuk akta otentik. Ada Beberapa hal yang harus dimuat dalam perjanjian lisensi, yakni: ${ }^{17}$ (1) Nama dan alamat para pihak yang mengadakan perj anjian lisensi; (2) Merek dan nomor pendaftarannya; (3) Ketentuan mengenai: (a) Jangka waktu perjanjian lisensi; (b) Dapat atau tidaknya jangka waktu perjanjian lisensi diperpanjang; (c) Penggunaan mereknya untuk seluruh atau sebagian jenis barang atau jasa yang termasuk dalam satu kelas; (c.1) J umlah royalty dan tata cara pembayarannya; (c.2) Dapat atau tidaknya penerima lisensi mem-berikan lisensi lanjut kepada pihak ketiga; (c.3) Kewajiban pemberi lisensi untuk melakukan pengawasan dan pembinaan terhadap mutu barang yang diproduksi dan diperdagangkan; (c.4) Batas wilayah berlakunya perjanjian lisensi, apabila diperjanjikan.

Penting untuk diperhatikan agar perjanj $\mathrm{i}$ an lisensi dapat berjalan dengan baik adalah pengaturan mengenai hak dan kewajiban licensor dan licensee secara rinci. Hak dan kewajiban pemberi lisensi adalah: ${ }^{18}$ menerima pembayaran royalty sesuai dengan perjanjian; tetap berhak menggunakan sendiri mereknya; menuntut pembatalan lisensi merek, apabila penerima lisensi tidak melaksanakan perjanjian sebagai-

\footnotetext{
${ }^{16}$ Keberadaan unsur itikad baik dalam hukum kontrak modern diakui sebagai elemen penting dari para pihak untuk mengontrol dan mengawasi ketentuan-ketentuan kontrak serta pelaksanaan kontrak, sehingga dapat dipahami jika berbagai ketentuan hukum kontrak yang ada selalu menempatkan unsur itikad baik sebagai unsur penting dan memberikan akibat yang patal jika unsur itikad baik tidak terpenuhi dalam kontrak. Samuel Hutabarat, Prinsip Itikad Baik Dalam berbagai Hukum Kontrak, Jurnal Gloria J uris, Vol. 4, No. 3, SeptemberDesember 2004, hlm. 223-224

${ }^{17}$ Agung Sujatmiko, "Aspek Yuridis Lisensi ...", op.cit., hlm. 255

${ }^{18}$ lbid., hlm. 256
} 
mana mestinya; menjamin penggunaan merek dari cacat hukum atau gugatan dari pihak ketiga; me-lakukan pembinaan dan pengawasan terhadap mutu barang atau jasa hasil produksi penerima lisensi; meminta persetujuan kepada penerima lisensi, apabila pemberi lisensi mengajukan permintaan penghapusan mereknya; pem-batalan perjanjian lisensi merek, apabila pemberi lisensi tidak melaksanakan perjanjian sebagaimana mestinya. Sedangkan hak dan kewajiban penerima lisensi adalah: menggunakan merek yang dilisensikan sesuai dengan jangka waktu yang telah ditentukan dalam perjanjian; menuntut pembayaran kembali bagian royalty yang telah dibayarkan penerima lisensi kepada pemilik merek yang telah dibatalkan; memberi lisensi lebih lanjut kepada pihak ketiga, sesuai dengan perjanjian; menuntut pembatalan lisensi merek, apabila pemberi lisensi tidak melaksanakan perjanjian sebagaimana mestinya; membayar royalty sesuai dengan perjanjian; meminta pencatatan perjanjian lisensi kepada Kantor Merek; menjaga mutu barang atau jasa hasil produksinya sesuai dengan standar mutu barang atau jasa atas merek yang dilisensikan.

Perjanjian lisensi tidak hanya memberikan manfaat bagi penerima lisensi saja, melainkan juga pemberi lisensi. ${ }^{19}$ Manfaat bagi penerima lisensi berupa pemakaian merek pemberi lisensi secara legal dengan berbagai keuntungan yang melekat pada merek yang bersangkutan. Jika merek yang dilisensikan tersebut ternyata merek terkenal dengan reputasi baik, maka penerima lisensi akan dapat menjalankan usahanya dengan mudah, karena pada umumnya masyarakat akan tertarik untuk membeli produk dengan merek yang sudah terkenal. J adi penerima lisensi tidak perlu repot membuat merek sendiri dan mendaftarkan mereknya yang memerlukan waktu, tenaga dan biaya. Penerima lisensi hanya ber-kewajiban untuk mencatatkan perjanjian lisensi. Sedangkan manfaat bagi pemberi lisensi selain memperoleh royalty adalah mereknya dijamin akan dipakai oleh penerima lisensi secara legal sehingga secara langsung merupakan bentuk perlindungan hukum

\footnotetext{
${ }^{19}$ Lihat Agung Sujatmiko, "Prinsip Hukum Kontrak ...”, op. cit., hlm. 99-100.
}

kepada mereknya dan terhindar dari upaya peng-hapusan merek.

Perjanjian lisensi berlaku diseluruh wilayah Negara Republik Indonesia (kecuali jika diperjanjikan lain), untuk jangka waktu yang tidak lebih lama dari jangka waktu perlindungan merek terdaftar yang bersangkutan. Pemilik merek terdaftar yang telah memberikan lisensi kepada pihak lain, tetap dapat menggunakan sendiri atau memberikan lisensi kepada pihak ketiga lainnya untuk menggunakan merek tersebut (kecuali bila diperjanjikan lain). Dalam perjanjian lisensi dapat ditentukan bahwa penerima lisensi bisa memberikan lisensi lebih lanjut kepada pihak ketiga. Perjanjian lisensi dilarang memuat ketentuan baik yang langsung maupun tidak langsung dapat menimbulkan akibat yang merugikan perekonomian Indonesia atau memuat pembatasan yang menghambat kemampuan bangsa Indonesia dalam menguasai dan mengembangkan teknologi pada umumnya.

Perjanjian lisensi wajib dimohonkan pencatatannya (oleh penerima lisensi) pada Direktorat J enderal Hak Kekayaan Intelektual untuk dicatat dalam Daftar Umum Merek dan selanjutnya diumumkan dalam Berita Resmi Merek. Akibat hukum dari pencatatan per-janjian lisensi berlaku terhadap pihak-pihak yang bersangkutan dan terhadap pihak ketiga.

\section{Pembatalan Pendaftaran Merek}

Pembatalan pendaftaran merek hanya dapat diajukan oleh pihak yang berkepentingan atau oleh pemilik merek, baik dalam bentuk permohonan kepada Direktorat J enderal Hak Kekayaan Intelektual atau gugatan kepada Pengadilan Niaga, dengan dasar alasan sebagaimana dimaksud dalam Pasal 4, Pasal 5, atau Pasal 6 UU Merek yang mengatur mengenai merek yang tidak dapat didaftarkan dan merek yang ditolak pendaftarannya. Meskipun UndangUndang sudah mengatur ketentuan pendaftaran merek sedemikian rupa, namun pada praktiknya seringkali timbul beberapa masalah dalam pemeriksaan merek. Paling menonjol adalah yang berkaitan dengan "itikad baik" dan "persamaan". Bagaimana menentukan ada tidaknya suatu itikad baik dan persamaan merek, baik 
persamaan pada pokoknya maupun persamaan pada keseluruhannya seperti diatur dalam Pasal 4 dan Pasal 6 ayat (1) huruf a adalah hal yang tidak mudah.

Menurut Pasal 4 UU Merek, merek tidak dapat didaftar atas dasar permohonan yang diajukan oleh pemohon yang beritikad tidak baik. Dalam penjelasannya disebutkan, pemohon yang beritikad baik adalah pemohon yang mendaftarkan mereknya secara layak dan jujur tanpa ada niat apapun untuk membonceng, meniru, atau menjiplak ketenaran merek pihak lain demi kepentingan usahanya yang berakibat kerugian pada pihak lain itu atau menimbulkan kondisi persaingan curang, mengecoh atau menyesatkan konsumen. ${ }^{20}$

Secara umum jangkauan pengertian itikad tidak baik meliputi perbuatan "penipuan" (fraud), rangkaian "menyesatkan" (misleading) orang lain, serta tingkah laku yang mengabaikan kewajiban hukum untuk mendapat keuntungan. Bisa juga diartikan sebagai perilaku yang tidak dibenarkan secara sadar untuk mencapai suatu tujuan yang tidak jujur (dishonesthy purpose). Dalam pengkajian merek, setiap perbuatan peniruan, reproduksi, mengkopi, membajak atau membonceng kemasyuran merek orang lain dianggap sebagai perbuatan pemalsuan, penyesatan atau memakai merek orang lain tanpa hak (unauthorized use) yang secara harmonisasi dalam perlindungan merek di-kualifikasikan sebagai persaingan curang (unfair competition) serta dinyatakan sebagai perbuatan mencari kekayaan secara tidak jujur (unjust enrichment). ${ }^{21}$

Mengenai persamaan pada pokoknya, Penjelasan Pasal 6 ayat (1) huruf a menegaskan yang dimaksud dengan persamaan pada pokoknya adalah kemiripan yang disebabkan oleh adanya unsur-unsur yang menonjol antara merek yang satu dengan merek yang lain, yang

\footnotetext{
20 Lihat Anny Retnowati, “Tinjauan YuridisTerhadap Tindak Pidana "Memperdagangkan Barang Merek Palsu Dengan Pendekatan Kasus Putusan Perkara No. 215/ Pid. B/2005/ PN.SLMN", J urnal J ustitia Et Pax, Atma J aya Yogyakarta, Vol. 28 No. 2, Desember 2008, hlm. 167

${ }^{21}$ Lihat Agus Mardianto, "Penghapusan Pendaftaran Merek Berdasarkan Gugatan Pihak Ketiga", Jurnal Dinamika Hukum, Unsoed Purwokerto, Vol. 10 No. 1, J anuari 2010, hlm. 47.
}

dapat menimbulkan kesan adanya persamaan baik mengenai bentuk, cara penempatan, cara penulisan atau kombinasi antara unsur-unsur ataupun persamaan bunyi ucapan yang ter-dapat dalam merek-merek tersebut.

World Trade Mark Symposium di Cannes (1992) memberikan beberapa unsur yang dapat di-gunakan sebagai patokan untuk menilai persamaan pada pokoknya, yaitu persamaan penampilan (similarity of appearance); persamaan bunyi (sound similarity); persamaan konotasi (connotation similarity); persamaan kesan dalam perdagangan (similarity in commercial impression); dan persamaan jalur perdagangan (trade cannel similarity). Sedangkan Wayne Covell memberikan beberapa indikator untuk menilai persamaan pada pokoknya: persamaan visual (visual similarity), persamaan kemasan (packaging similarity), persamaan dalam asosiasi (similarity in association), dan persamaan fungsi serta pemakaian (similarity in function and use). ${ }^{22}$

Ada doktrin yang dapat dipergunakan untuk menentukan ada tidaknya persamaan merek menurut Amalia Rooseno, yaitu doktrin entireties similiar dan doktrin nearly resembles. ${ }^{23}$ Doktrin entireties similiar menganggap persamaan keseluruhan elemen adalah standar, dalam hal ini merek yang diminta untuk didaftarkan merupakan copy reproduksi merek orang lain. Ajaran ini dianggap terlalu kaku dan tidak dapat melindungi kepentingan pemilik merek, khususnya untuk merek terkenal. Doktrin nearly resembles menganggap suatu merek mempunyai persamaan pada pokoknya dengan merek orang lain jika pada merek tersebut terdapat kemiripan (identical) atau hampir mirip dengan merek orang lain, yang dapat didasarkan pada kemiripan gambar, susunan kata, warna atau bunyi. Persamaan pada pokoknya tidak mutlak ditegaskan pada persamaan semua elemen merek dan tidak dituntut keras adanya jalur pemasaran yang sama. ${ }^{24}$ Faktor yang paling pokok

\footnotetext{
22 Lihat Tomi Suryo Utomo, op. cit., hlm. 222-223.

${ }^{23}$ Lihat Agus Mardianto, op.cit, hlm. 44.

24 Patokan untuk menentukan persamaan pada pokoknya yang dipakai doktrin nearly resembles lebih lentur dibandingkan dengan doktrin entireties similar. Antory Royan Adyan, "Perlindungan Hukum Terhadap Pelanggaran
} 
dalam doktrin ini adalah pemakaian merek yang mempunyai persamaan pada pokoknya ini dapat menimbulkan kebingungan yang nyata (actual confusion) atau menyesatkan (decieve) masyarakat konsumen. Seolah-olah merek tersebut berasal dari sumber atau produsen yang sama. Sehingga di dalamnya terlihat unsur iktikad tidak baik untuk membonceng ketenaran merek milik orang lain. ${ }^{25}$

Teori lain yang dapat dikemukakan adaIah Teori holistic approach dan Teori dominancy. Menurut Teori holistic approach untuk menentukan ada tidaknya persamaan merek harus dilihat secara keseluruhan, baik dari bunyinya, artinya, ejaannya maupun dari tampilannya. Teori dominancy menentukan adanya persamaan merek antara merek yang satu dengan yang lainnya cukup diambil unsur yang dianggap paling dominan dari merek tersebut. ${ }^{26}$

Gugatan pembatalan pendaftaran merek $^{27}$ dapat diajukan oleh pemilik merek yang terdaftar lebih dahulu berdasarkan alasan mempunyai persamaan pada pokoknya atau keseluruhan. Gugatan diajukan kepada Pengadilan Niaga. Apabila gugatan pembatalan pendataran merek dikabulkan, maka isi putusan Pengadilan Niaga tersebut segera disampaikan oleh panitera kepada Direktorat J enderal Hak Kekayaan Intelektual setelah tanggal putusan diucapkan. Kemudian Direktorat J enderal Hak Kekayaan Intelektual melaksanakan pembatalan pendaftaran merek yang bersangkutan dari Daftar Umum Merek dan mengumumkannya dalam Berita Resmi Merek setelah putusan di terima dan mempunyai kekuatan hukum tetap.

Pembatalan pendaftaraan merek dilakukan oleh Direktorat Jenderal Hak Kekayaan Intelektual dengan mencoret merek yang bersangkutan dari Daftar Umum Merek dengan memberi catatan tentang alasan dan tanggal pembatalan tersebut. Pembatalan pendaftar-

Penggunaan Hak Merek", Law Riview, Volume VII Nomor 3, Februari 2008, hlm. 104

${ }^{25}$ Agus Mardianto, op.cit, hlm. 44

26 lbid., hlm. 55.

27 Selain dapat diajukan oleh pemilik merek yang terdaftar lebih dahulu, gugatan juga dapat diajukan oleh pihak yang berkepentingan, antara lain: jaksa, yayasan/lembaga di bidang konsumen, dan majelis/lembaga keagamaan. an merek diberitahukan secara tertulis kepada pemilik merek atau kuasanya. Pencoretan pendaftaran suatu merek dari Daftar Umum Merek diumumkan dalam Berita resmi Merek. Sejak tanggal pencoretan sertifikat merek yang bersangkutan dinyatakan tidak berlaku lagi. Pembatalan dan pencoretan pendaftaran merek mengakibatkan berakhirnya perlindungan hukum atas merek yang bersangkutan.

\section{Akibat Pembatalan Pendaftaran Merek ter- hadap Hak Penerima Lisensi Merek}

Pembatalan pendaftaran merek akan berakibat berakhirnya perjanjian lisensi yang di buat antara pemberi lisensi (yang mereknya sudah dibatalkan) dengan penerima lisensi. Walaupun demikian hak penerima lisensi masih tetap dilindungi, hal ini dapat di lihat dalam Pasal 48 UU Merek yang menentukan sebagai berikut: (a) Penerima Lisensi yang beriktikad baik, tetapi kemudian Merek itu dibatalkan atas dasar adanya persamaan pada pokoknya atau keseluruhannya dengan Merek lain yang terdaftar, tetap berhak melaksanakan perjanjian Lisensi tersebut sampai dengan berakhirnya jangka waktu perjanjian Lisensi; (b) Penerima Lisensi sebagaimana dimaksud pada ayat (1) tidak lagi wajib meneruskan pembayaran royalti kepada pemberi Lisensi yang dibatalkan, melainkan waj ib melaksanakan pembayaran royalti kepada pemilik Merek yang tidak dibatalkan; (c) Dalam hal pemberi Lisensi sudah terlebih dahulu menerima royalti secara sekaligus dari penerima Lisensi, pemberi Lisensi tersebut wajib menyerahkan bagian dari royalti yang diterimanya kepada pemilik Merek yang tidak dibatalkan, yang besarnya sebanding dengan sisa jangka waktu perjanjian Lisensi.

Pasal 48 UU Merek memberikan perlindungan hukum kepada penerima lisensi merek yang beritikad baik, namun tidak menjelaskan bagaimana definisi dari seorang penerima lisensi beritikad baik sehingga dipandang perlu untuk menghubungkannya dengan pasal 43 (3) UU Merek tentang keharusan pencatatan perjanjian lisensi pada direktorat jenderal Hak Kekayaan Intelektual. Pencatatan perjanjian lisensi biasanya dilakukan oleh penerima lisensi (de- 
ngan itikad baik), karena akibat hukum dari pencatatan perjanjian lisensi berlaku terhadap para pihak yang bersangkutan dan terhadap pihak ketiga.

Apabila dalam pelaksanaan perjanjian lisensi tersebut terjadi gugatan pembatalan terhadap kepemilikan Merek (berdasarkan alasan bahwa merek yang bersangkutan mempunyai persamaan pada pokoknya atau secara keseluruhan) yang ditujukan kepada pemilik merek sekaligus pem-beri lisensi merek, maka kedudukan dari pihak penerima lisensi merek tidak akan terpengaruhi oleh putusan hakim yang berkekuatan hukum tetap terhadap sengketa gugatan merek tersebut. Apabila kedudukan pemberi lisensi merek sebagai pemilik merek dibatalkan melalui putusan hakim pengadilan niaga yang berkekuatan hukum tetap, maka pihak penerima lisensi merek akan tetap dapat melaksanakan perjanjian lisensi tersebut dan dengan persyaratan bahwa pembayaran royalti pada periode selanjutnya akan dilanjutkan kepada pihak yang dinyatakan sebagai pemilik merek yang sah.

\section{Penutup}

Simpulan

Pembatalan Pendaftaran Merek berakibat berakhirnya perjanjian lisensi merek, akan tetapi pembatalan pendaftaran merek tidak berakibat hapusnya hak penerima lisensi merek. Pasal 48 UU Merek memberikan perlindungan terhadap hak penerima lisensi merek yang beritikad baik yang mencatatkan perjanjian lisensi yang dibuatnya pada Direktorat Jenderal Hak Kekayaan Intelektual. Penerima lisensi merek tersebut tetap berhak melaksanakan perjanjian Lisensi sampai dengan berakhirnya jangka waktu perjanjian Lisensi.

\section{Daftar Pustaka}

Adyan, Antory Royan. "Perlindungan Hukum Terhadap Pelanggaran Penggunaan Hak Merek". Law Riview, Volume VII Nomor 3, Februari 2008;

Bustamin, A. "Kebebasan Berkontrak Hubungannya Dengan Perjanjian Baku". Jurnal
Aktualita, Vol. I, No. 2 Agustus-November 2005;

Ginting, Gloria Gita Putri. "Perlindungan Hukum Dalam Bidang Merek". Jurnal Suloh, Vol. III No. 1 April 2005;

Hadiarianti, Venantia. “Konsep Dasar Pemberian Hak dan perlindungan Hukum Hak kekayaan Intelektual". J urnal Gloria J uris, Vol. 8, No. 2, Mei-Agustus 2008;

Hutabarat, Samuel. "Prinsip Itikad Baik Dalam berbagai Hukum Kontrak". Jurnal Gloria J uris, Vol. 4, No. 3, September-Desember 2004;

Mardianto, Agus. "Penghapusan Pendaftaran Merek Berdasarkan Gugatan Pihak Ketiga". J urnal Dinamika Hukum, Vol. 10 No. 1, J anuari 2010. Unsoed Purwokerto;

Muhammad, Abdulkadir. 2001. Kajian Hukum Ekonomi Hak Kekayaan Intelektual. Citra Aditya: Bandung

Retnowati, Anny. "Tinjauan YuridisTerhadap Tindak Pidana "Memperdagangkan Barang Merek Palsu Dengan Pendekatan Kasus Putusan Perkara No. 215/ Pid.B/2005/ PN.SLMN". Jurnal J ustitia Et Pax, Atma J aya Yogyakarta, Vol. 28 No. 2, Desember 2008;

Selvie, Valerie. "Domain Name and Mark Issues on The Internet: The Perspective of Australian Law". Jurnal Gloria Juris, Vol. 5, Nomor 3, September-Desember 2005;

------. "Perlindungan Hukum Merek Terkenal Tidak Terdaftar di Indonesia". Jurnal Gloria J uris, Vol. 6, No. 2, Mei - Agustus 2006;

Simanjuntak, Ricardo. "Asas-Asas Utama Hukum Kontrak dalam Kontrak Dagang Internasional: sebuah Tinjauan Hukum". Jurnal Hukum Bisnis, Vol. 27, No. 4 Tahun 2008;

Stiarto, Noegroho Amin. "Hak Atas Kekayaan Intelektual dan Hak Kekayaan Intelektual Tradisional dalam Konteks Otonomi Daerah". Jurnal Mimbar Hukum Edisi Tahun 2000;

Suj atmiko, Agung. "Aspek Yuridis Lisensi Merek dan Persaingan Usaha". J urnal Hukum Pro Justitia, Vol. 26 No.2, April 2008. UNPAR Bandung;

"Prinsip Hukum Kontrak dalam Lisensi Merek". J urnal Mimbar Hukum, Vol. 20, nomor 2, J uni 2008; 
Suryomurcito, Gunawan (Ketua Tim). 2006. Laporan Akhir Tentang Kompilasi Bidang Hukum Perjanjian Lisensi. Jakarta: BPHN Departemen Hukum dan Hak Asasi Manusia;

Syafrinaldi. "Urgensi dan Permasalahan Harmonisasi Undang-Undang Merek Terhadap Protokol Madrid". Jurnal Hukum Bisnis, Vol. 28 No. 2 Tahun 2009;

Syafrinaldi; "Hak Milik Intelektual dan Lisensi Sebagai Sarana Alih Teknologi"; J urnal II- mu Hukum, Vol. 1 No. 1 April 2009. Unis Riau;

Utomo, Tomi Suryo. 2010. Hak Kekayaan Intelektual (HKI) di Era Global (Sebuah Kajian Kontemporer). Yogyakarta: Graha II$\mathrm{mu}$;

Wijaya, H.R. Tonny Suryadi. "Perlindungan Merek di Indonesia Menurut Undang-Undang Nomor 15 Tahun 2001 Tentang Merek". Perspektif Hukum, Volume 7 Nomor 1 , Mei 2007. 